\title{
Cow Dung Substrate for the Potential Production of Alkaline Proteases by Pseudomonas putida Strain AT in Solid-State Fermentation
}

\author{
Ponnuswamy Vijayaraghavan, ${ }^{1}$ Sreekumar Saranya, ${ }^{2}$ and Samuel Gnana Prakash Vincent ${ }^{1}$ \\ ${ }^{1}$ International Centre for Nanobiotechnology, Centre for Marine Science and Technology, Manonmaniam Sundaranar University, \\ Rajakkamangalam, Kanyakumari District, Tamil Nadu 629 502, India \\ ${ }^{2}$ Xpression Biotek, Akash Tower, Pammam, Marthandam, Kanyakumari District, Tamil Nadu 629 165, India
}

Correspondence should be addressed to Ponnuswamy Vijayaraghavan; venzymes@gmail.com

Received 25 August 2013; Accepted 9 October 2013; Published 1 January 2014

Academic Editors: Z. Tan and R. Tofalo

Copyright (C) 2014 Ponnuswamy Vijayaraghavan et al. This is an open access article distributed under the Creative Commons Attribution License, which permits unrestricted use, distribution, and reproduction in any medium, provided the original work is properly cited.

\begin{abstract}
Cow dung and agroresidues were used as the substrates for the production of alkaline proteases by Pseudomonas putida strain AT in solid-state fermentation. Among the various substrates evaluated, cow dung supported maximum $(1351 \pm 217 \mathrm{U} / \mathrm{g})$ protease production. The optimum conditions for the production of alkaline proteases were a fermentation period of $48 \mathrm{~h}, 120 \%$ ( $/ \mathrm{w}$ ) moisture, $\mathrm{pH} 9$, and the addition of $6 \%(\mathrm{v} / \mathrm{w})$ inoculum, $1.5 \%(\mathrm{w} / \mathrm{w})$ trehalose, and $2.0 \%(\mathrm{w} / \mathrm{w})$ yeast extract to the cow dung substrate. The enzyme was active over a range of temperatures $\left(50-70^{\circ} \mathrm{C}\right)$ and $\mathrm{pHs}(8-10)$, with maximum activity at $60^{\circ} \mathrm{C}$ and $\mathrm{pH}$ 9. These enzymes showed stability towards surfactants, detergents, and solvent and digested various natural proteins.
\end{abstract}

\section{Introduction}

Proteases constitute one of the commercially important groups of extracellular microbial enzymes and their annual sales account for $60 \%$ of the total world enzyme market [1]. Extracellular proteases find numerous applications in industrial processes, such as detergents, leather-tanning, dairy, meat-tenderization, baking, brewery, and photographic industry [2]. From an industrial point of view, it is estimated that around $30-40 \%$ of the production cost of industrial enzymes can be attributed to the cost of the growth medium [3]. According to Global Food Enzymes Market Report, it is expected that the global food enzyme market will reach $\$ 2.3$ billion by 2018; North America is expected to lead the market, followed by Europe and Asia-Pacific.

Solid-state fermentation (SSF) is preferred over submerged fermentation, because of its lower production cost. Agroindustrial residues which included wheat bran [4]; green gram husk [5]; coffee pulp and coffee husk [6]; and Imperata cylindrica grass and potato peel [7] were widely used in SSF. In this study, cow dung substrate (referred to as dungstrate hereafter) was used as a cheap substrate for the production of alkaline proteases for various biotechnological applications. Cow dung consists of ash (13.3-13.4\%), nitrogen (1.2-1.6\%), carbon sources, ions, and growth factors. As waste, cow dung still contains high amount of nutrients [8]. A few reports were available on the use of cow dung for the production of alkaline proteases, for example, cow dung and Halomonas sp. PV1 [9] and cow dung and Bacillus subtilis VV [10]. But there might hardly be any reports on the use of cow dung for the production of proteases by Pseudomonas sp. Even though Bacillus spp. have been viewed as a promising group of organisms for protease production for various industrial applications, Pseudomonas protease has also been considered for many applications. Most of the Pseudomonas spp. are capable of synthesizing solvent tolerant proteases: for example, $P$. aeruginosa Pst [11], $P$. aeruginosa PST-01 [12], P. aeruginosa strain K [13], and P. fluorescens [14]. Due to the importance of Pseudomonas proteases for various applications, cow dung could contribute significantly as a solid substrate in enzyme bioprocess and thus may help to reduce production costs. 
Proteases have been optimized and characterized from Pseudomonas sp. using many kinds of wastes, including animal fleshing and fish waste [15] as the sole source of carbon and nitrogen. In addition to carbon and nitrogen sources, $\mathrm{pH}$ and temperature were also known to influence the extracellular enzyme secretion, by changing the physical properties of the cell membrane $[13,16]$. However, factors like media components play a major role in protease production [17]. Apart from the nutritional factors, selection of the right organism plays a key role in the high yield of desirable enzymes. In order to produce enzymes for industrial use, isolation and characterization of new promising strains using cheap carbon and nitrogen sources is a continuous process. The microbial strain is unique in its molecular, biochemical, metabolic, and enzyme production properties. Hence, an indepth knowledge of kinetics and the catalytic behavior during protease production from any new strain is a prerequisite for the evaluation of its biotechnological potential [5]. Hence, the aim of the present investigation was to use cow dung for the production of alkaline proteases by Pseudomonas putida strain AT under SSF and to find its properties.

\section{Materials and Methods}

2.1. Chemicals. Sephadex G-75 was purchased from Amersham Biosciences, Sweden. All other chemicals were purchased from Merck (Bangalore, India) and Himedia (Mumbai, India) unless otherwise stated.

Isolation and identification of proteolytic enzyme-producing microorganisms Pseudomonas putida strain AT was isolated nearby the milk processing centre (Nagercoil area, South India). One $\mathrm{mL}$ of discarded milk was taken from the plastic container, which was contaminated with soil and degraded feather. This sample was mixed with sterile double distilled water and then spread on skimmed milk agar plates composed of $0.5 \%(\mathrm{w} / \mathrm{v})$ peptone, $0.5 \%(\mathrm{w} / \mathrm{v})$ yeast extract, $1 \%(\mathrm{w} / \mathrm{v}) \mathrm{KH}_{2} \mathrm{PO}_{4}, 0.02 \%(\mathrm{w} / \mathrm{v}) \mathrm{MgSO}_{4}, 1 \%(\mathrm{w} / \mathrm{v})$ skimmed milk, $1 \%(\mathrm{w} / \mathrm{v}) \mathrm{NaCl}$, and $1.5 \%(\mathrm{w} / \mathrm{v})$ agar. Isolates displaying relatively high proteolytic activity on these plates were further cultured in flasks for quantitative analysis. Using this process, one strain exhibiting the highest proteolytic activity was ultimately selected. Bacterial identification was conducted based on "Bergey's Manual of Systematic Bacteriology" [18] and on the $16 \mathrm{~S}$ rDNA sequence analysis. The $16 \mathrm{~s}$ rDNA sequence obtained was subjected to BLAST analysis for species relationship [19]. The $1409 \mathrm{bp}$ sequence was submitted to GenBank (accession number: KC469288).

2.2. Solid-State Fermentation. Agroindustrial residues such as apple peels, oil cake, paddy straw, pine apple peels, redbanana, peels, potato peels, saw dust, rice bran, and cow dung were collected locally. These solids were dried for several days at room temperature. These were powdered using a mixer grinder, sieved, and stored in airtight container before further use. Ten grams of the solid substrates was taken in a $250 \mathrm{~mL}$ Erlenmeyer flask and the moisture content was maintained as $100 \%$ using tris- $\mathrm{HCl}$ buffer ( $\mathrm{pH} 8.0,0.1 \mathrm{M})$. The contents were mixed and autoclaved at $121^{\circ} \mathrm{C}$ for $30 \mathrm{~min}$.
After cooling the flask to room temperature, it was inoculated with $0.5 \mathrm{~mL}$ of $24 \mathrm{~h}$ grown (OD600 $\mathrm{nm}=1.038)$ culture broth under sterile conditions. These were incubated for $72 \mathrm{~h}$ at $37^{\circ} \mathrm{C}$ and after incubation $50 \mathrm{~mL}$ of double distilled water was added to the fermented substrate. This was placed in an orbital shaker at $175 \mathrm{rpm}$ of $30 \mathrm{~min}$ for enzyme extraction. After this, the mixture was filtered using cotton and the cells were further harvested by centrifugation at $10000 \mathrm{~g}$ for $20 \mathrm{~min}$. The supernatant was used as the enzyme source for protease assay.

\subsection{Optimization of Alkaline Protease Production in SSF. To} determine the optimum incubation time on enzyme production, the organism was inoculated with dungstrate and incubated for $12-96 \mathrm{~h}$. To find the optimum $\mathrm{pH}$ for enzyme secretion, the substrate was moistened with buffers at various $\mathrm{pH}$ values (6 to 11). Different particle sizes ( $1 \mathrm{~mm}-4 \mathrm{~mm}$ ) were applied to evaluate the optimum particle size. To determine the optimum moisture and inoculum level, the predetermined quantity of moisture (40-140\%) and inoculum (2$10 \%)$ were maintained individually for optimized enzyme production. The effects of various carbon (maltose, xylose, glucose, starch, trehalose, and sucrose) sources $(1 \%, \mathrm{w} / \mathrm{w})$ and nitrogen (peptone, casein, yeast extract, ammonium sulphate, and urea) sources $(1 \%, \mathrm{w} / \mathrm{w})$ were also evaluated by supplementing carbon and nitrogen sources separately. The maximum production of proteases at various concentrations $(0.5-2.5 \%)$ of trehalose as the carbon source and yeast extract as the nitrogen source was investigated. Effect of each parameter was studied in triplicate and the data are graphically presented as the mean \pm standard deviation of triplicate $(n=3)$.

2.4. Enzyme Extraction and Assay. Alkaline protease activity was determined by Kim et al. [20] with little modification. The reaction mixture contained casein (prepared in $0.05 \mathrm{M}$ of Tris- $\mathrm{HCl}$ buffer, $\mathrm{pH}$ 8.0) and an aliquots of enzyme solution, and this mixture was incubated for $30 \mathrm{~min}$ at $37^{\circ} \mathrm{C}$. The reaction was stopped by adding $2.5 \mathrm{~mL}$ of trichloroacetic acid solution (TCA) $(0.11 \mathrm{M})$ and the mixture was centrifuged (10000 g, $10 \mathrm{~min})$. The optical density of the solution was read against sample blank at $280 \mathrm{~nm}$. One unit of the alkaline protease activity was defined as $1 \mu \mathrm{g}$ of tyrosine liberated $\mathrm{min}^{-1}$ under assay conditions. The protein content was determined by the Bradford's method.

2.5. Partial Purification of Enzyme. The crude enzyme was precipitated with ammonium sulphate (30-70\% saturation) and the protein was collected by centrifugation $(10000 \mathrm{~g}$, $20 \mathrm{~min}$ ) and dissolved in Tris- $\mathrm{HCl}$ buffer ( $\mathrm{pH} 8,0.05 \mathrm{M})$. The sample was dialyzed against double distilled water. Two milliliter of dialyzed sample was applied to a prepacked Sephadex G-75 gel filtration column at a flow rate of $0.5 \mathrm{~mL}$ $\min ^{-1}$. The fractions of $2 \mathrm{~mL}$ were collected and analysed for proteolytic activity.

2.6. Enzyme Characterization. The active fractions obtained from the gel filtration chromatography were pooled and used 
for characterization studies. Protease activity was measured as described earlier in the following buffer system $(0.1 \mathrm{M})$ : succinic acid (5), sodium phosphate (6-7), Tris- $\mathrm{HCl}(8)$, and glycine- $\mathrm{NaOH}$ (9-10), respectively. To check the stability of the enzyme at various $\mathrm{pHs}$, the enzyme solution was mixed with the above buffer solution and incubated for $1 \mathrm{~h}$ at $37^{\circ} \mathrm{C}$. To determine the optimal temperature for the protease, the assay was carried out under various temperatures ranging from 30 to $70^{\circ} \mathrm{C}$. To determine the enzyme stability, the enzyme was subjected to denaturation at different temperatures $\left(30\right.$ to $\left.70^{\circ} \mathrm{C}\right)$ for $1 \mathrm{~h}$, and then the remaining activities were measured at standard assay conditions. To study the effect of ions on enzyme activity, the sample was preincubated with various divalent ions $(0.01 \mathrm{M})\left(\mathrm{Ca}^{2+}, \mathrm{Mg}^{2+}, \mathrm{Cu}^{2+}, \mathrm{Fe}^{2+}\right.$, $\mathrm{Hg}^{2+}$, and $\mathrm{Zn}^{2+}$ ) at $37^{\circ} \mathrm{C}$ for $1 \mathrm{~h}$ and the activity was evaluated.

2.7. Activity of Alkaline Proteases on Solvent, Surfactant, Detergent, and Natural Proteins. The effects of various solvent (1\%) (ethanol, methanol, acetone, acetonitrile, benzene, toluene and butanol), surfactants (1\%) (SDS, Tween 20, Tween 80, and Triton X-100), and commercial detergents (1\%) (Sunlight, Mr. White, Henko, Ujala, Tide+, Ariel, and Surfexcel) on protease activity were determined by incubating them with the samples for $1 \mathrm{~h}$ at $37^{\circ} \mathrm{C}$ and the residual activities were measured by the standard assay procedure. To evaluate the digestibility of natural proteins, crude enzyme $(5 \mathrm{U})$ was incubated with sheep skin $(2 \times 2 \mathrm{~cm})$, sheep blood clot $(1.0 \mathrm{~g})$, BSA $(1 \%, w / v)$, and egg white $(1 \%, v / v)$ in $0.05 \mathrm{M}$ Tris- $\mathrm{HCl}$ $(\mathrm{pH} 9)$ at $30^{\circ} \mathrm{C}$. Conditions of the substrates were monitored after 12 and $24 \mathrm{~h}$.

\section{Results}

3.1. Isolation and Characterization of a Protease Secreting Bacterium. From the samples, 17 microorganisms showing protease activity were screened. Amongst them, Pseudomonas putida strain AT was chosen for further investigation in the light of exhibiting a relatively strong proteolytic activity. The skimmed milk degrading isolate was Gram-negative motile aerobic rods. The organism was nitrate-, catalase- positive and urease-negative. The organism exhibited starch-hydrolyzing effect and was seen to produce acid when fructose, galactose, mannitol, sucrose, and trehalose were added to it. The $16 \mathrm{~S}$ rDNA sequence of the isolate $(1409 \mathrm{bp})$ was deposited at GenBank (accession no: KC469288).

3.2. Screening of Various Agroindustrial Residues for Alkaline Protease Production. Many different agroindustrial residues and cow dung were utilized for protease production. All the substrates that were tested supported protease production, but the yield varied with the type of substrate used. The maximum enzyme production $(1351 \pm 217 \mathrm{U} / \mathrm{g})$ was observed with dungstrate (cow dung substrate) than with other agroresidues (Figure 1).

3.3. Influence of Incubation Time, $p H$, and Particle Size. The protease production increased linearly with increase in incubation time up to $48 \mathrm{~h}(5660 \pm 361 \mathrm{U} / \mathrm{g})$ as shown in Figure 2

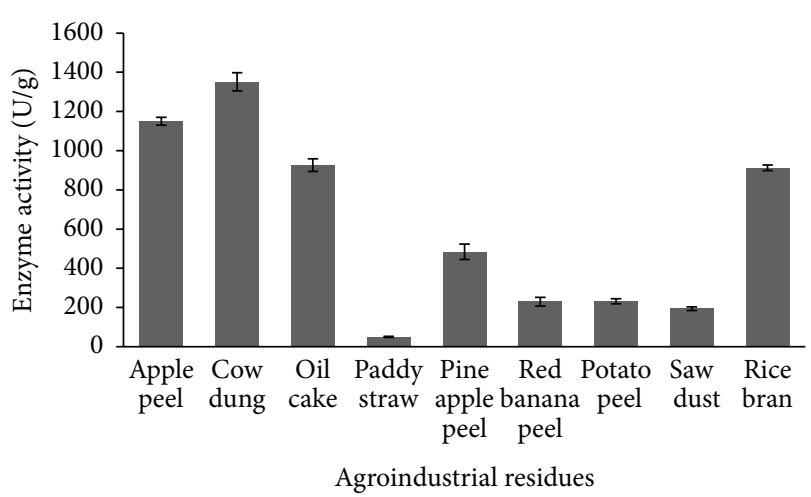

FIGURE 1: Evaluation of agroindustrial wastes for the production of alkaline proteases.

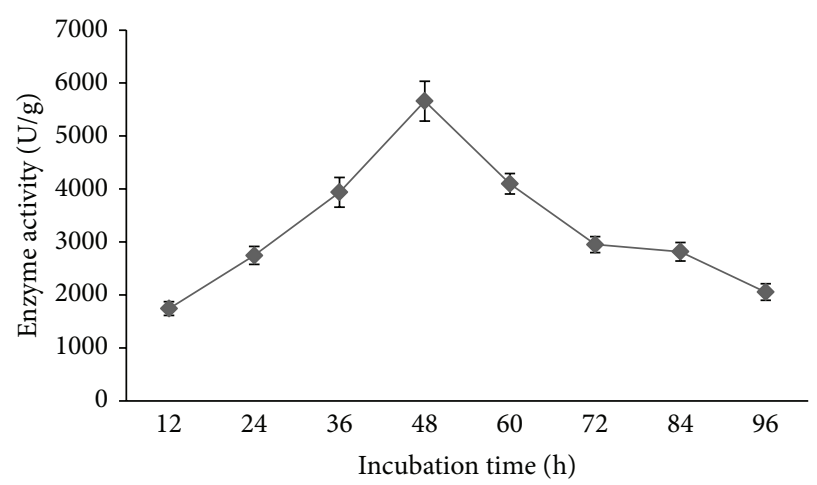

FIGURE 2: Effect of fermentation period of enzyme production on dungstrate.

and decreased thereafter. In the present study, the enzyme production was found to be high at alkaline $\mathrm{pHs}$ than at the acidic pHs. The enzyme production gradually increased with increase in the $\mathrm{pH}$ of the medium, and the maximum production $(5709 \pm 361 \mathrm{U} / \mathrm{g})$ was recorded at $\mathrm{pH} 9$. The enzyme production was $1333 \pm 114 \mathrm{U} / g, 1904 \pm 151 \mathrm{U} / \mathrm{g}$, $4935 \pm 365 \mathrm{U} / \mathrm{g}, 5548 \pm 412 \mathrm{U} / \mathrm{g}$, and $4307 \pm 313 \mathrm{U} / \mathrm{g}$ of dungstrate at $\mathrm{pHs}$ of $5,6,7,8$, and 10 , respectively. The maximum enzyme production was observed at a particle size of approximately $1 \mathrm{~mm}(5684 \pm 378 \mathrm{U} / \mathrm{g})$ and the enzyme production was adversely affected for other particle sizes (data not shown).

3.4. Effect of Moisture and Inoculum. In the present study, the maximum enzyme production was observed with a $120 \%$ moisture content $(6585 \pm 251 \mathrm{U} / \mathrm{g})$. Enzyme productions were $1343 \pm 202 \mathrm{U} / \mathrm{g}, 3913 \pm 128 \mathrm{U} / \mathrm{g}, 4584 \pm 412 \mathrm{U} / \mathrm{g}$, $5847 \pm 378 \mathrm{U} / \mathrm{g}$, and $3786 \pm 361 \mathrm{U} / \mathrm{g}$ dungstrate for $40 \%$, $60 \%, 80 \%, 100 \%$, and $140 \%$ moisture, respectively. At lower and higher initial moisture levels the enzyme production was significantly affected. In the present study, there was a significant increase in the alkaline protease production with an increase in inoculum size up to an optimal level of $6 \%(6426 \pm 317 \mathrm{U} / \mathrm{g})$ after which the protease production decreased. Enzyme productions were $872 \pm 48 \mathrm{U} / \mathrm{g}$, 


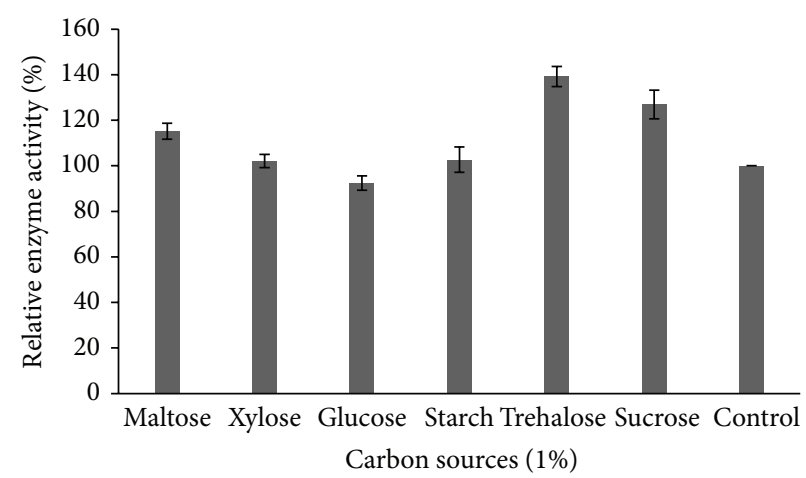

(a)

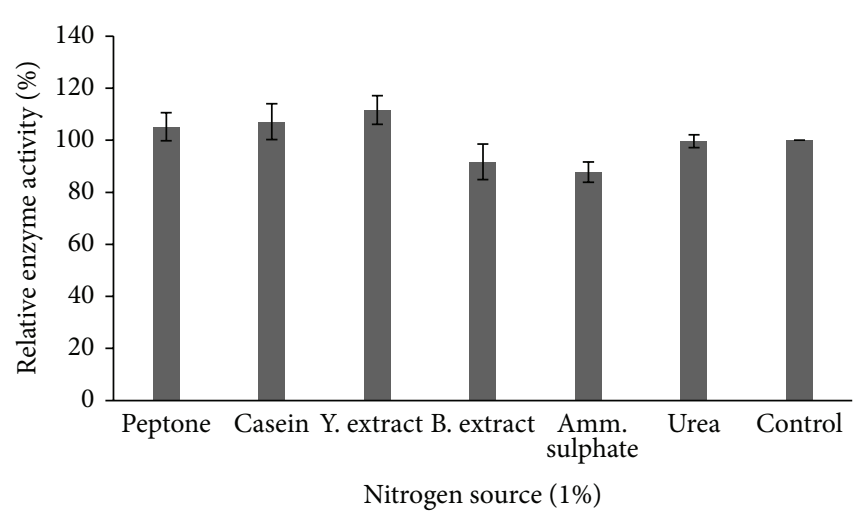

(b)

FIGURE 3: (a) Effect of carbon sources on alkaline proteases production. (b) Effect of nitrogen sources on enzymes production.

$1946 \pm 113 \mathrm{U} / \mathrm{g}, 3828 \pm 98 \mathrm{U} / \mathrm{g}$, and $2621 \pm 112 \mathrm{U} / \mathrm{g}$ dungstrate, for inoculums of $2 \%, 4 \%, 8 \%$, and $10 \%$, respectively.

3.5. Effect of Carbon and Nitrogen Sources. Carbon sources such as maltose, xylose, glucose, starch, trehalose, and sucrose were supplemented with dungstrate separately at $1 \%$ level. Among the various carbon sources tested, trehalose and sucrose supported the maximum production of protease with $7941 \pm 250 \mathrm{U} / \mathrm{g}$ and $7239 \pm 342 \mathrm{U} / \mathrm{g}$, respectively (Figure 3(a)). When different concentrations of trehalose were tested, $1.5 \%$ trehalose supported the maximum protease production with $8778 \pm 159 \mathrm{U} / \mathrm{g}$. Among the various nitrogen sources tested, yeast extract showed the maximum production of protease with $6294 \pm 308 \mathrm{U} / \mathrm{g}$ (Figure 3(b)). When different concentrations of yeast extract were tested, $2 \%$ yeast extract supported the maximum protease production $(6644 \pm 462 \mathrm{U} / \mathrm{g})$.

3.6. Enzyme Characterization. The partially purified sample was used to study the effect of $\mathrm{pH}$, temperature and ions on enzyme activity. The optimum protease activity was determined to be $\mathrm{pH} 9(100 \pm 6.1 \%)$, suggesting that it is an alkaline protease. The enzyme was stable from $\mathrm{pH} 7$ to 9 for $1 \mathrm{~h}$ (Figure 4).

The maximum protease activity recorded was between 50 and $70^{\circ} \mathrm{C}$ under assay conditions, while the activity decreased rapidly above $70^{\circ} \mathrm{C}$. By analyzing its thermal stability, the protease was found to be stable for temperatures up to $50^{\circ} \mathrm{C}$ for $1 \mathrm{~h}$ incubation and lost around $6 \pm 0.2 \%$ and $31 \pm 0.18 \%$ activity at $60^{\circ} \mathrm{C}$ and $70^{\circ} \mathrm{C}$, respectively (Figure 5). The ions $(0.010 \mathrm{M})$ were preincubated with sample for $1 \mathrm{~h}$ and enzyme activity was evaluated. All of the ions tested were inhibited enzyme activity. Ions such as $\mathrm{Cu}^{2+}, \mathrm{Hg}^{2+}$, and $\mathrm{Zn}^{2+}$ strongly inhibited enzyme activity, and the enzyme activities were $1.9 \pm$ $0.04 \%, 0 \%$, and $34 \pm 1.7 \%$, respectively. $\mathrm{Ca}^{2+}, \mathrm{Mn}^{2+}$, and $\mathrm{Mg}^{2+}$ showed activities of $97 \pm 2.3 \%, 96.8 \pm 3.1 \%$, and $96.2 \pm 1.2 \%$, respectively.

3.7. Activity of Alkaline Protease on Solvent, Surfactants, Detergents, and Natural Proteins. The enzyme showed stability in the presence of tested organic solvents. The relative enzyme

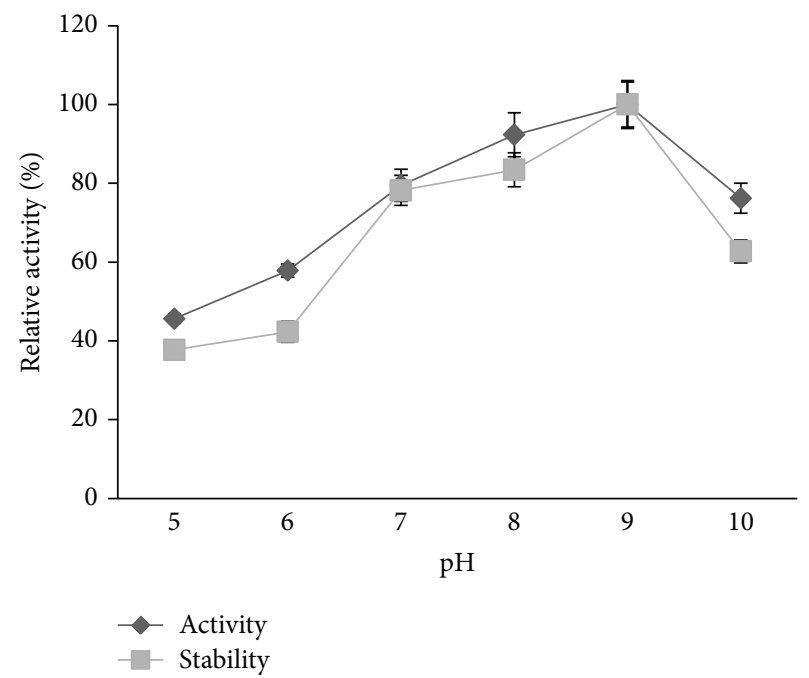

FIGURE 4: Effect of pH on enzyme activity and stability.

activity was found to be high $(124.8 \pm 3.6 \%$ and $106 \pm$ $2.9 \%$ ), for ethanol and acetonitrile, respectively (Figure 6). All the surfactants that were tested showed enzyme activity. The enzyme activity was $89.6 \pm 2.8 \%$ when the enzyme solution was incubated with $1 \%$ SDS (Figure 7). Protease from Pseudomonas putida strain AT retained more activity after $1 \mathrm{~h}$ incubation at $37^{\circ} \mathrm{C}$ in the presence of the detergents such as Sun light, Mr. White, Henko, Ujala, and Tide+ (Figure 8). These enzymes digested the natural proteins such as blood clots, BSA, egg white, and sheep skin within $24 \mathrm{~h}$ of incubation at room temperature $\left(30 \pm 2^{\circ} \mathrm{C}\right)$.

\section{Discussion}

A potent Pseudomonas putida strain AT exhibited significant protease production by utilizing dungstrate as the fermentation medium. As shown in Figure 1, the enzyme production was significantly high in cow dung than in the agroresidues that were tested. This result was in accordance with the observations made recently with Halomonas sp. PV1 and 


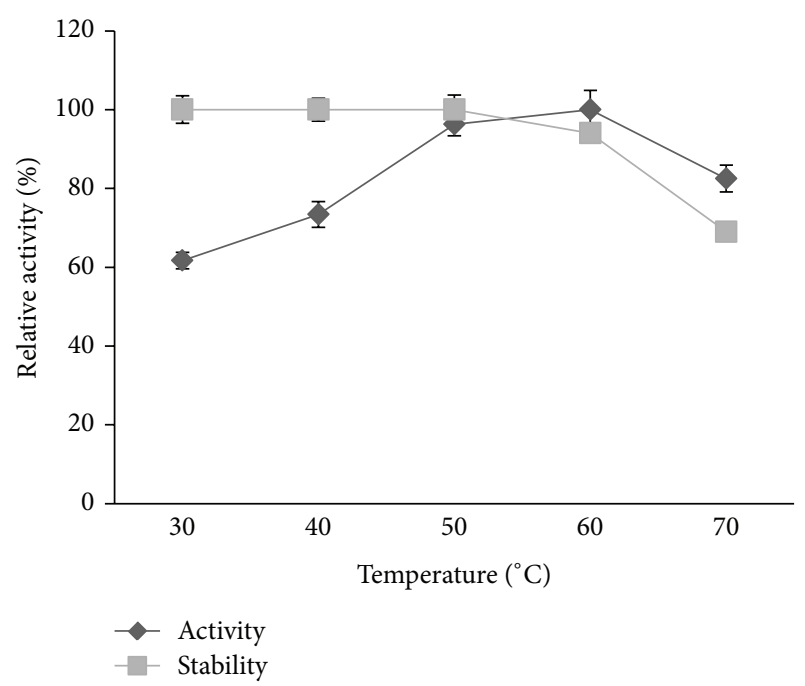

FIGURE 5: Effect of temperature on enzyme activity and stability.

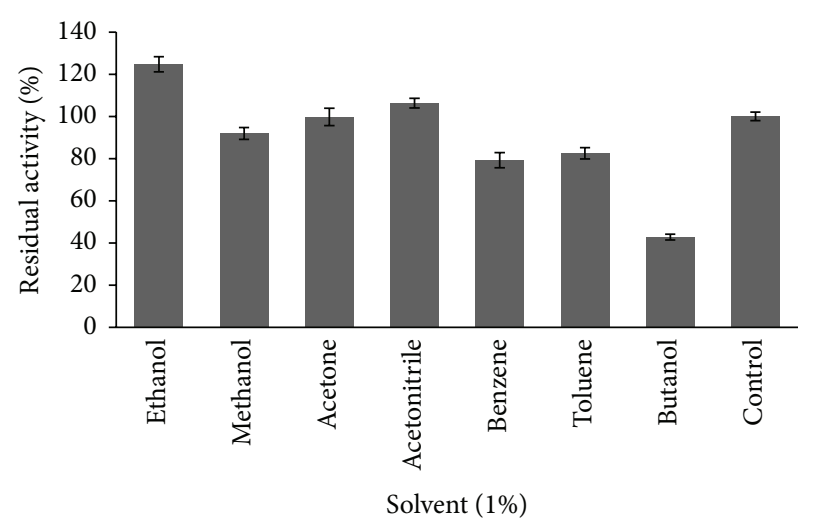

FIGURE 6: Effect of solvent on enzyme stability.

Bacillus subtilis strain VV $[9,10]$. This substrate was able to provide all the necessary nutrients for the growth of the bacterium and for the synthesis of the enzymes. Alkaline proteases have been produced by various bacteria by utilizing many natural substrates, for example, animal fleshing [21], shrimp/crab shell powder [22], fish wastes [15], and poultry wastes [23]. These substrates were not available during all seasons and the handling/processing cost was more than that of dungstrate. The selection of an ideal agroindustrial residue for enzyme production in an SSF process depends on several factors, including cost and availability [6]. Hence, this study is significantly important because of the reduced cost of the dungstrate and its availability. According to the report, the wet weight of the total dung production for the year 2003 was estimated at about 562 million tonnes. Cow dung contains a variety of nutrient sources (ash: $30.5 \%$, total carbon: $38.6-42.5 \%$, total nitrogen: $1.29-1.7 \%$, C-N ratio: $18-$ $25.1 \%$, sulphur: $0.18 \%$ ) [24]. So these nutrients could support the growth of the microorganisms and the production of enzymes.

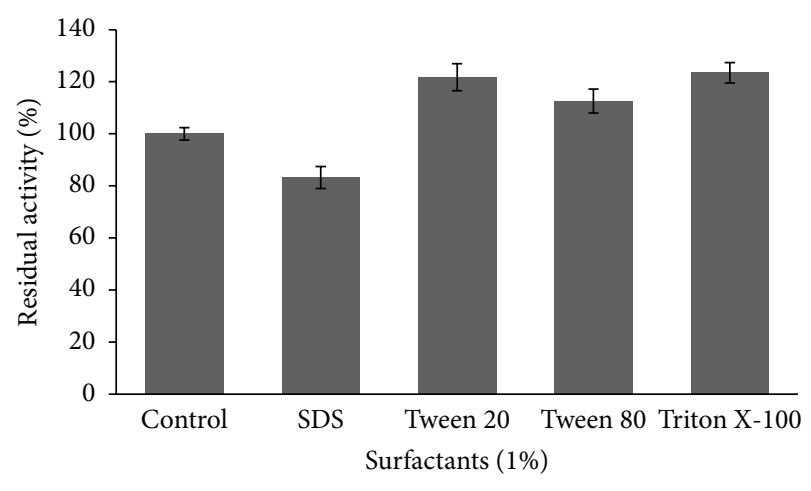

FIGURE 7: Effect of surfactants on enzyme stability.

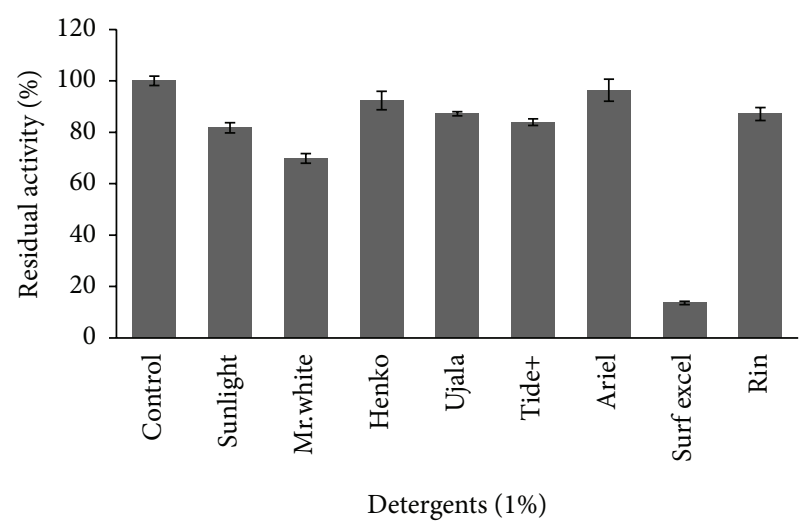

FIGURE 8: Effect of detergents on enzyme stability.

In the present study, a maximum of $5660 \pm 217 \mathrm{U} / \mathrm{g}$ was recorded after $48 \mathrm{~h}$ of incubation with dungstrate with a moisture content of $100 \%$. The reduction in enzyme yield after the optimum period was probably due to the depletion of nutrients that were available to the micro-organisms. In the present study, the enzyme production was maximum at $\mathrm{pH} 9$ and decreased thereafter. At a higher $\mathrm{pH}$ level, protease production decreased, as the metabolic action of the bacterium could have been suppressed. These results are in accordance with observations made with the alkaliphilic Pseudomonas aeruginosa MTCC 7926 [25].

The maximum enzyme production was observed with particle sizes of approximately $1.0 \mathrm{~mm}$ and decreased for other particle sizes. This result was in accordance with observations made with other bacterial species for alkaline protease secretion using cow dung substrate [9]. In the present study, a maximum activity of $6585 \pm 413 \mathrm{U} / \mathrm{g}$ was recorded at $120 \%$ moisture content. The enzyme production was affected adversely at levels below or above the optimum. Low moisture content leads to suboptimal growth and a lower degree of substrate swelling which also affects enzyme production [26]. There was a significant increase in alkaline protease production with an increase in the inoculum size up to an optimum level $(6 \%)$. However, decreased enzyme production beyond the optimum level might be due to the exhaustion of nutrients in the fermentation medium. This result was in accordance with results observed with $P$. aeruginosa [25]. 
Among the various carbon sources tested, trehalose supported the maximum production of protease with an increase of $39.2 \pm 4.4 \%$ over control (Figure $3(\mathrm{a})$ ). These results are in accordance with other reports of alkaline protease production in the presence of different sugars [27]. Among the various nitrogen sources tested, yeast extract exhibited the maximum production of protease $(6294 \pm 308 \mathrm{U} / \mathrm{g})$ (Figure 3(b)). Similar observations were noticed in case of protease production by different microbial species $[5,6]$. Pseudomonas putida strain AT proteases were active in a wide $\mathrm{pH}$ range (8-10) and were stable over a $\mathrm{pH}$ range of 8-10 (Figure 4). Similar kinds of $\mathrm{pH}$ stability of protease produced by Pseudomonas aeruginosa PT121 have been described earlier [28]. Maximum protease activity (100\%) was determined at $60^{\circ} \mathrm{C}$ and it declined at higher temperatures (Figure 5). This result is in accordance with the observations made with $P$. aeruginosa [29] and other bacterial species [30]. The enzyme had a halflife of $60 \mathrm{~min}$ at $50^{\circ} \mathrm{C}$ and less than $50 \mathrm{~min}$ at $60^{\circ} \mathrm{C}$.

The influence of various divalent ions on the protease activity of Pseudomonas putida strain AT was also investigated. A significant inhibitory effect on the protease activity was observed with $\mathrm{Hg}^{2+}, \mathrm{Zn}^{2+}$, and $\mathrm{Cu}^{2+}$ ions $(0.01 \mathrm{M})$. These demonstrated that these alkaline proteases are metalindependent and these do not require any metal ions for its activity. Likewise, Najafi et al. [31] reported a metal-independent protease from $P$. aeruginosa PD100. This enzyme was stable towards organic solvent such as ethanol, acetonitrile, and acetone, respectively. This result is accordance with observations made with Pseudomonas aeruginosa [13]. The alkaline protease was stable towards the surfactants like Tween 20, Tween 80, Triton X-100, and SDS. This finding gains significance, because the modern bleach-based detergent formulation is mainly composed of SDS. This result was in accordance with the observation made recently with other bacterial species [10]. Microbial alkaline proteases have a lot of applications in detergent industry [32]. The alkaline protease was stable towards commercially available detergents and these enzymatic properties suggest its suitability as an addition to detergent formulations. Similar kinds of results were reported with other bacterial species [3].

The Pseudomonas putida strain AT protease digested many natural proteins. After $24 \mathrm{~h}$ of incubation of the sample with blood clot, chicken albumin, goat hides, and BSA, it digested all these natural proteins. These properties of proteases were characterized by Iyappan et al. [29] with the Pseudomonas aeruginosa PD100. The capabilities of these proteases to digest different natural substrates suggest the usefulness of these enzymes for various applications.

\section{Conclusion}

In the present study, cow dung was used as an effective substrate in enzyme bioprocess. The alkaline protease from Pseudomonas putida strain AT was active in a range of temperatures and $\mathrm{pHs}$. This enzyme was surfactant-, detergent-, and solvent-stable and digested various natural proteins.

\section{Conflict of Interests}

The authors declare that they have no conflict of interests.

\section{Acknowledgments}

One of the authors, P. Vijayaraghavan, is thankful to the Council of Scientific and Industrial Research, New Delhi, India, for financial support in the form of a Senior Research Fellowship. S. Saranya is thankful to Department of Biotechnology, New Delhi, India, for "Biotech Industrial Training Programme."

\section{References}

[1] B. Turk, "Targeting proteases: successes, failures and future prospects," Nature Reviews Drug Discovery, vol. 5, no. 9, pp. 785799, 2006.

[2] V. Moses and R. E. Cape, Biotechnology, the Science and Business, Harwood Academic publishers, 1991.

[3] H.-S. Joo, C. G. Kumar, G.-C. Park, S. R. Paik, and C.-S. Chang, "Oxidant and SDS-stable alkaline protease from Bacillus clausii I-52: production and some properties," Journal of Applied Microbiology, vol. 95, no. 2, pp. 267-272, 2003.

[4] R. Rajkumar, J. K. Ranishree, and R. Ramasamy, "Production and characterization of a novel protease from Bacillus sp. RRM1 under solid state fermentation," Journal of Microbiology and Biotechnology, vol. 21, no. 6, pp. 627-636, 2011.

[5] R. S. Prakasham, C. S. Rao, and P. N. Sarma, "Green gram huskan inexpensive substrate for alkaline protease production by Bacillus sp. in solid-state fermentation," Bioresource Technology, vol. 97, no. 13, pp. 1449-1454, 2006.

[6] A. Pandey, C. R. Soccol, P. Nigam, D. Brand, R. Mohan, and S. Roussos, "Biotechnological potential of coffee pulp and coffee husk for bioprocesses," Biochemical Engineering Journal, vol. 6, no. 2, pp. 153-162, 2000.

[7] A. K. Mukherjee, H. Adhikari, and S. K. Rai, "Production of alkaline protease by a thermophilic Bacillus subtilis under solidstate fermentation (SSF) condition using Imperata cylindrica grass and potato peel as low-cost medium: characterization and application of enzyme in detergent formulation," Biochemical Engineering Journal, vol. 39, no. 2, pp. 353-361, 2008.

[8] R. V. Misra, R. N. Roy, and H. Hiraoka, On Farm Composting Method, FAO, Rome, Italy.

[9] P. Vijayaraghavan and S. G. P. Vincent, "Cow dung as a novel, inexpensive substrate for the production of a halo-tolerant alkaline protease by Halomonas sp. PV1 for eco-friendly applications," Biochemical Engineering Journal, vol. 69, pp. 57-60, 2012.

[10] P. Vijayaraghavan, A. Vijayan, A. Arun, J. K. Jenisha, and S. G. P. Vincent, "Cow dung: a potential biomass substrate for the production of detergent-stable dehairing protease by alkaliphilic Bacillus subtilis strain VV,' SpringerPlus, vol. 1, article 76, 2012.

[11] A. Gupta, I. Roy, R. K. Patel, S. P. Singh, S. K. Khare, and M. N. Gupta, "One-step purification and characterization of an alkaline protease from haloalkaliphilic Bacillus sp," Journal of Chromatography A, vol. 1075, no. 1-2, pp. 103-108, 2005.

[12] H. Ogino, K. Yasui, T. Shiotani, T. Ishihara, and H. Ishikawa, "Organic solvent-tolerant bacterium which secretes an organic solvent-stable proteolytic enzyme," Applied and Environmental Microbiology, vol. 61, no. 12, pp. 4258-4262, 1995. 
[13] R. Rahman, L. P. Geok, M. Basri, and A. B. Salleh, "An organic solvent-tolerant protease from Pseudomonas aeruginosa strain $\mathrm{K}$ : nutritional factors affecting protease production," Enzyme and Microbial Technology, vol. 36, no. 5-6, pp. 749-757, 2005.

[14] H. Kumura, K. Mikawa, and Z. Saito, "Purification and some properties of proteinase from Pseudomonas fluorescens," Journal of Dairy Research, vol. 60, no. 2, pp. 229-237, 1993.

[15] Y. Triki-Ellouz, B. Ghorbel, N. Souissi, S. Kammoun, and M. Nasri, "Biosynthesis of protease by Pseudomonas aeruginosa MN7 grown on fish substrate," World Journal of Microbiology and Biotechnology, vol. 19, no. 1, pp. 41-45, 2003.

[16] K. Kalaiarasi and P. U. Sunitha, "Optimization of alkaline protease production from Pseudomonas fluorescens isolated from meat waste contaminated soil," African Journal of Biotechnology, vol. 8, no. 24, pp. 7035-7041, 2009.

[17] R. Gupta, Q. K. Beg, S. Khan, and B. Chauhan, "An overview on fermentation, downstream processing and properties of microbial alkaline proteases," Applied Microbiology and Biotechnology, vol. 60, no. 4, pp. 381-395, 2003.

[18] D. Jones and M. D. Collins, "Irregular, nonsporeforming Grampositive rods," in Bergey's Manual of Systematic Bacteriology, $\mathrm{P}$. H. A. Sneath, Ed., vol. 2, pp. 1261-1434, Williams and Wilkins, Baltimore, Md, USA, 1984.

[19] W. G. Weisburg, S. M. Barns, D. A. Pelletier, and D. J. Lane, "16S ribosomal DNA amplification for phylogenetic study," Journal of Bacteriology, vol. 173, no. 2, pp. 697-703, 1991.

[20] D. C. Kim, N. S. Oh, and M. J. In, "Effect of carbon and nitrogen sources on cell growth and halotolerant alkaline protease production in Halomonas marisflava isolated from salt-fermented food," Food Science and Biotechnology, vol. 13, pp. 837-840, 2004.

[21] A. G. Kumar, S. Swarnalatha, B. Sairam, and G. Sekaran, "Production of alkaline protease by Pseudomonas aeruginosa using proteinaceous solid waste generated from leather manufacturing industries," Bioresource Technology, vol. 99, no. 6, pp. 19391944,2008

[22] S.-L. Wang, C.-H. Yang, T.-W. Liang, and Y.-H. Yen, "Optimization of conditions for protease production by Chryseobacterium taeanense TKU001," Bioresource Technology, vol. 99, no. 9, pp. 3700-3707, 2008

[23] P. Manivasagan, J. Venkatesan, K. Sivakumar, and S.-K. Kim, "Production, characterization and antioxidant potential of protease from Streptomyces sp. MAB18 using poultry wastes," BioMed Research International, vol. 2013, Article ID 496586, 12 pages, 2013.

[24] M. S. Haque and M. N. Haque, "Studies on the effect of urine on biogas production," Bangladesh Journal of Scientific and Industrial Research, vol. 41, no. 1-2, pp. 23-32, 2006.

[25] U. Patil and A. Chaudhari, "Optimal production of alkaline protease from solvent-tolerant alkalophilic Pseudomonas aeruginosa MTCC 7926," Indian Journal of Biotechnology, vol. 10, no. 3, pp. 329-339, 2011.

[26] N. D. Mahadik, U. S. Puntambekar, K. B. Bastawde, J. M. Khire, and D. V. Gokhale, "Production of acidic lipase by Aspergillus niger in solid state fermentation," Process Biochemistry, vol. 38, no. 5, pp. 715-721, 2002.

[27] P. Ellaiah, B. Srinivasulu, and K. Adinarayana, "A review on microbial alkaline proteases," Journal of Scientific and Industrial Research, vol. 61, no. 9, pp. 690-704, 2002.

[28] X.-Y. Tang, B. Wu, H.-J. Ying, and B.-F. He, "Biochemical properties and potential applications of a solvent-stable protease from the high-yield protease producer Pseudomonas aeruginosa PT121," Applied Biochemistry and Biotechnology, vol. 160, no. 4, pp. 1017-1031, 2010.

[29] S. Iyappan, K. Ramasamy, and S. Barathi, "Statistical media optimization and comparative proteome analysis for protease production from isolated Pseudomonas aeruginosa," Journal of Pharmacy Research, vol. 5, no. 3, pp. 1451-1456, 2012.

[30] M. A. Hassan, B. M. Haroun, A. A. Amara, and E. A. Serour, "Production and characterization of keratinolytic protease from new wool-degrading Bacillus species isolated from Egyptian ecosystem," BioMed Research International, vol. 2013, Article ID 175012, 14 pages, 2013.

[31] M. F. Najafi, D. Deobagkar, and D. Deobagkar, "Potential application of protease isolated from Pseudomonas aeruginosa PD100," Electronic Journal of Biotechnology, vol. 8, no. 2, pp. 197203, 2005.

[32] D. Kumar, S. Savitri, N. Thakur, R. Verma, and T. C. Bhalla, "Microbial proteases and application as laundry detergent additive," Research Journal of Microbiology, vol. 3, no. 12, pp. 661-672, 2008. 

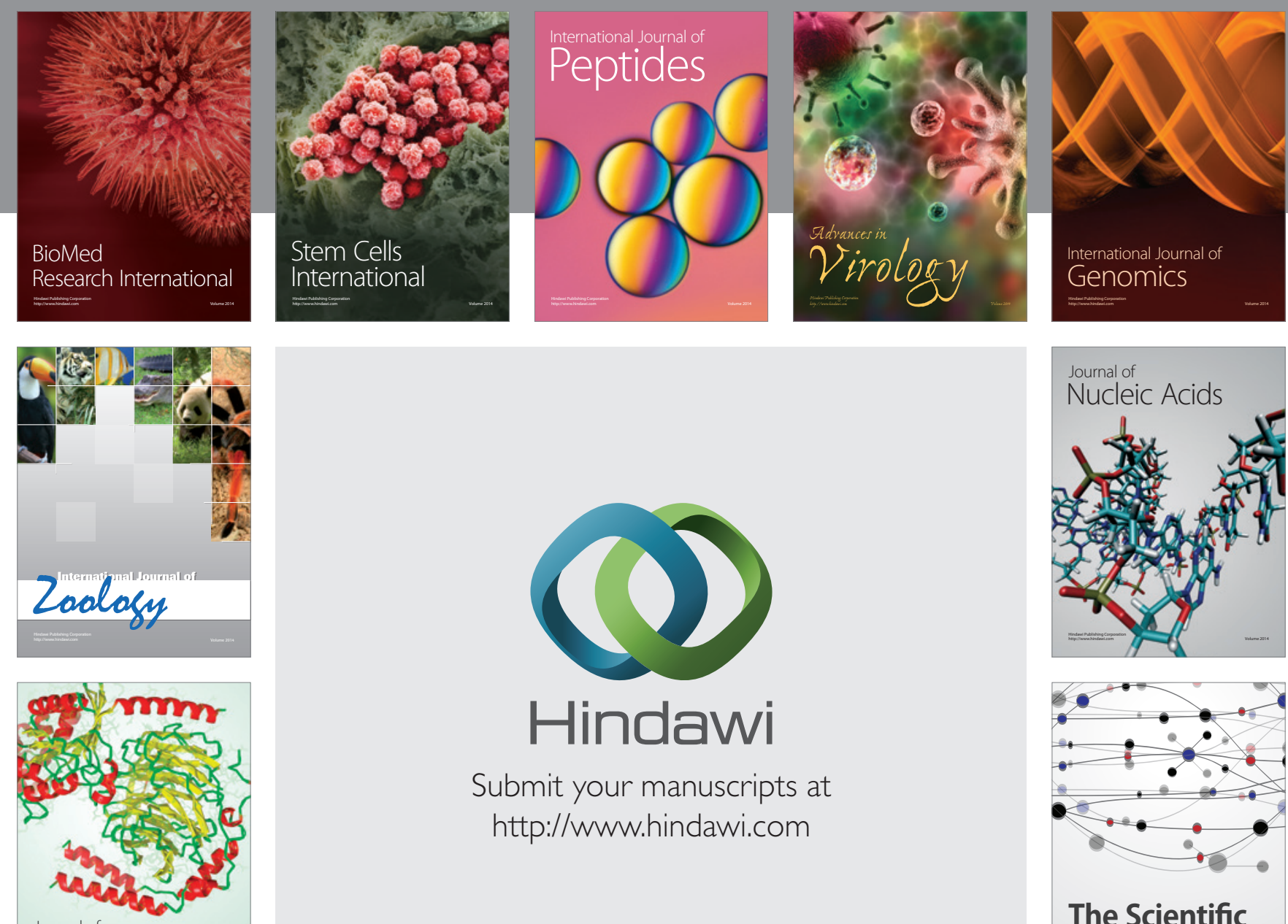

Submit your manuscripts at

http://www.hindawi.com

Journal of
Signal Transduction
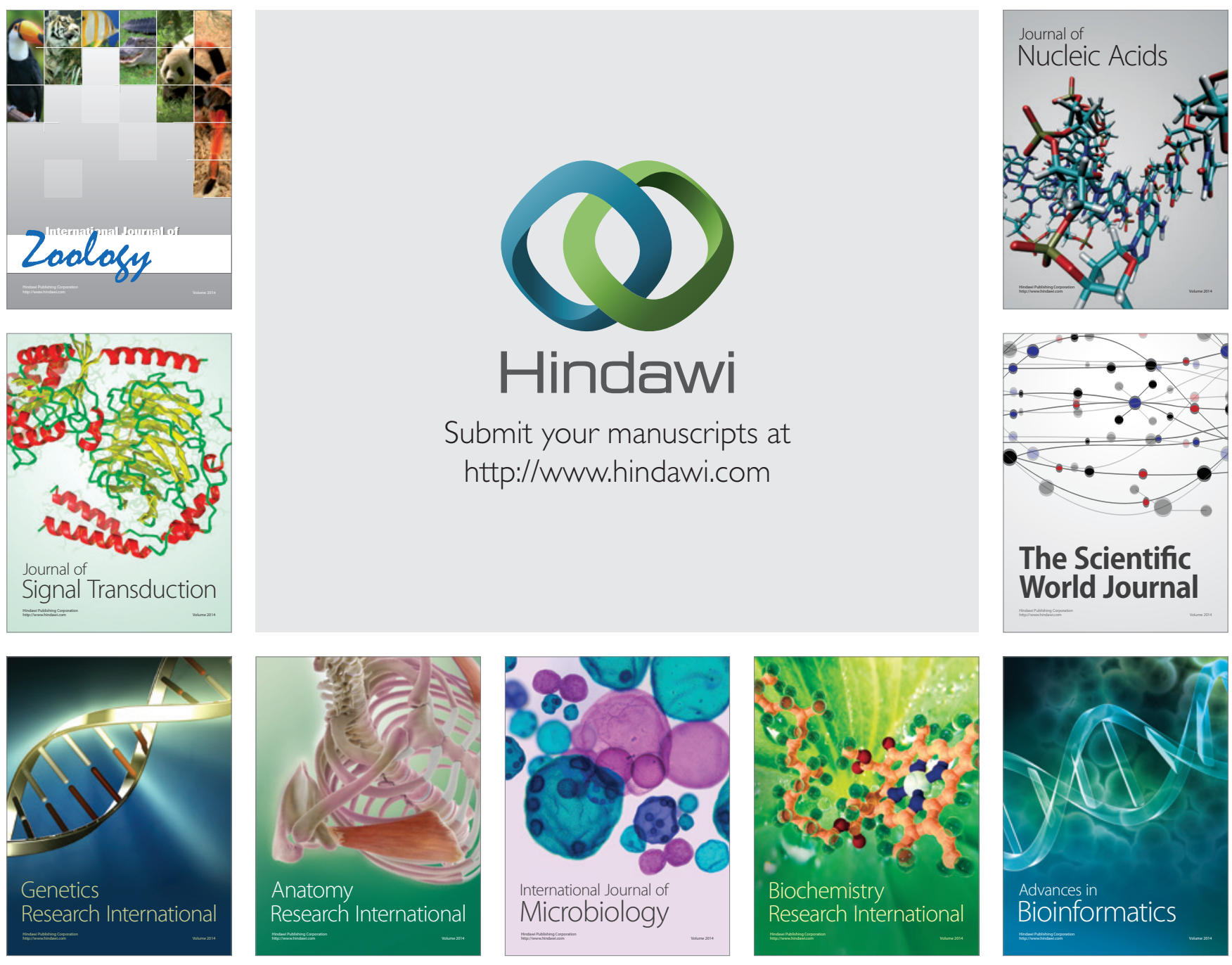

The Scientific World Journal
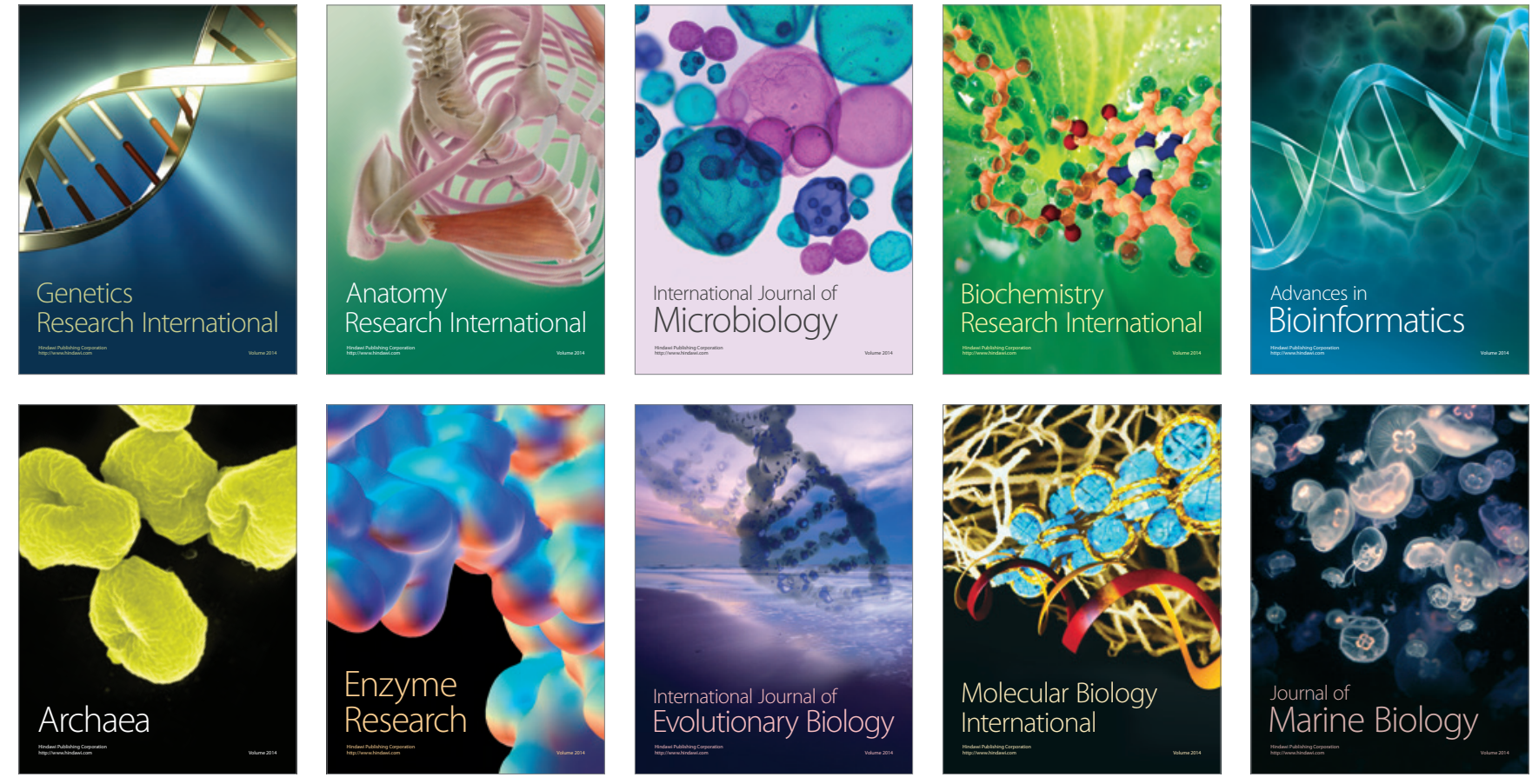